\title{
But where are you really from?
}

\section{The 'crisis' of multiculturalism examined through the work of four Asian-Australian artists}

\section{Anna Edmundson}

The first decade of the twenty-first century has seen a substantial shift in the ways in which issues of immigration, multiculturalism and citizenship have been debated in Australian political and public culture. As we near the end of this decade, 'multiculturalism' seems to be rapidly disappearing from government rhetoric (if not the political agenda altogether), with many analysts signalling a worldwide return to assimilation discourses. ${ }^{1}$ In lieu of this, it is timely to unpack some issues related to the current 'retreat' of multiculturalism and proposed 'return' of assimilation.

In this article, I want to explore the relationship between government-led doctrines on cultural diversity and constructions of national identity. ${ }^{2}$ I draw on the work of four artists of Asian-Australian descent, ${ }^{3}$ Liu Xiao Xian, Hou Leong, Owen Leong and Kate Beynon, to highlight some of the failings of current models of both multiculturalism and assimilation to effectively secure a place for non-Anglo and non-Indigenous Australians within the national imaginary. I have selected a work from each artist to serve as a lens for exploring some of the slippages that occur between different understandings of citizenship and cultural diversity: as government policy, as a concept of national identity and as a lived experience. ${ }^{4}$ In these works, the artists project a self-reflexive 'otherness' in relation to mainstream 'Australianness'. They also convey a more personal feeling of unease stemming from their sense of invisibility within the national imaginary. Ultimately, the artists remind us that, despite the Australian Government's attention to celebrating cultural difference, three decades of multiculturalism have failed to effectively shift the deeper historical structures and prejudices of Anglo-Australian (white) cultural hegemony.

During the course of my discussion, I try to pinpoint some of the reasons for this failure. First, I note that the transformation of the cultural landscape (from monocultural to multicultural) has been both rapid and radical, involving a major paradigm shift on government-led constructions of national identity. I draw on Jean Baudrillard's concept of 'simulacra' as a useful means of exploring the persistence of older representations of identity. Second, I suggest that a decade of sidelining of multiculturalism and cultural difference by the Howard Government (1996-2007) - heightened by a climate of increased racial tension linked to the rise of international terrorism and attendant anti-terrorist 
rhetoric - is now reflected in increased public confusion about and ambivalence towards multiculturalism (for those of Anglo-Australian descent and those whom the anthropologist Ghassan Hage has termed 'Third World-looking people'). ${ }^{5}$ Third, I argue that while multiculturalism was first envisioned by the Whitlam Government as a means of equalising differences between 'mainstream' and migrant communities, it has in many ways served only to further entrench ethnicity as the primary platform of socio-cultural difference and social fragmentation.

I conclude by arguing that a retreat from cultural pluralism in favour of current models of assimilation is bound to fail - if its intent, as is claimed, is the fostering of social inclusion. Not withstanding the primacy of Indigenous Australia, the complexity of our population calls for a more sophisticated and more inclusive model of citizenship and national identity, not a less inclusive one. It should be possible to construct a platform for citizenship and narratives of national identity, which genuinely reflects unity within diversity, rather than one in which, a priori, some people are selected to be second-class citizens based purely on their perceived ethnicity.

\section{Liu Xiao Xian's other lives}

The Ian Potter Centre-NGV Australian Art at Federation Square represents Australia's only major cultural institution devoted exclusively to Australian art. As such, it denotes a different kind of take on Australian history - one in which an emerging vision of Australia can be seen through the eyes of its resident artists. Shortly after the opening of the Ian Potter Centre, I was surprised to find a work by one of my favourite artists in the colonial and Federation-era galleries. The work is by Liu Xiao Xian, a sculptor and photographer who was born in Beijing in 1963 and migrated to Australia in 1990. So what was it doing among the colonial portraits and 'Heidelberg masters' of early Australian art? Its inclusion by the gallery's curators was at once witty and profound. As a curatorial intervention, it was effective in marking the physical presence of Chinese migrants during the time frame covered, while simultaneously highlighting their absence within the canonical (art) history.

The artwork appears at first glance to be a nineteenth-century stereograph print of the type that was widely popular during the Victorian era. Stereograph cameras produced a double print taken from slightly different focal points. When viewed through a wooden stereo-viewer, the prints merged to form a three-dimensional image. In Liu's work, the left-hand print shows a woman of European descent formally dressed in late-Victorian attire. In the right-hand print, the artist has inserted himself into the image (and into the past) as the woman's Asian doppelganger. The work, which is one of a larger series entitled My Other Lives, stems from Liu's interest in the history of Chinese migrants in Australia, particularly during the goldrush era. ${ }^{6}$ In this series, he has reworked old 
photographic portraits to appear as stereographs of typical Anglo-Australian family life during the colonial era with himself as the original sitter's double.

\section{Figure 7.1 Liu Xiao Xian, My Other Lives}

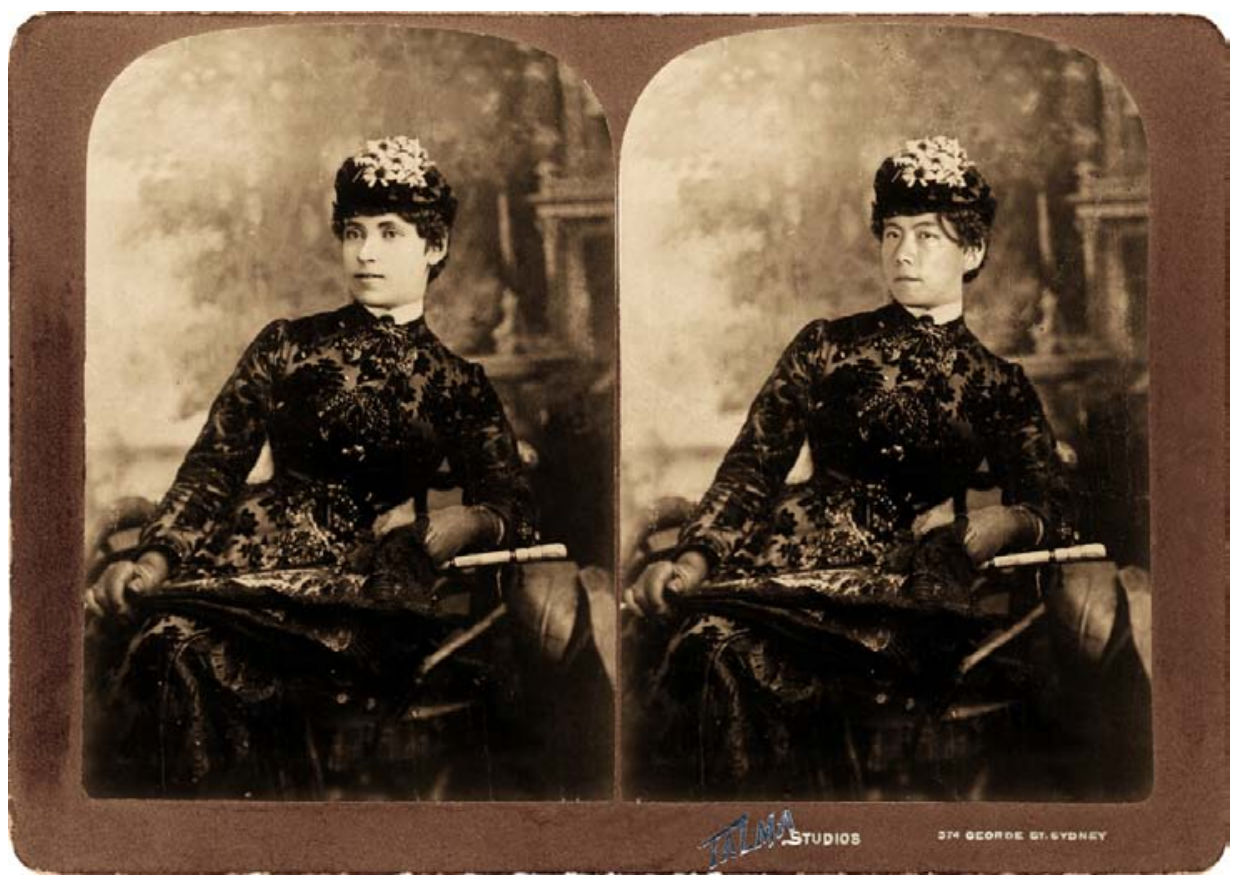

Liu Xiao Xian, My Other Lives, Stereograph series \#7, 2000; Lamda print, 100 x 150cm, edition of 10; Courtesy of the artist. Collection: National Gallery of Victoria, Melbourne, purchased with funds arranged by Loti Smorgon for Contemporary Australian Photography, 2002.

According to the exegesis that accompanies the work:

Xiao Xian Liu, an Eastern man performs roles in a Western History - he is the wife at home - the child with a toy - the dashing young man with a penny farthing bicycle. These are his other lives. These are the ancestors whose lives we know only so much about. ${ }^{7}$

In Liu's work, the juxtaposition of a European and Asian face is intended to reflect the invisibility of people of Asian origin in Australian history. ${ }^{8}$ Walking past the 'portrait', one might not catch the subtle, almost ambiguous renderings of identity. When you do notice the insertion and consequent inversion, you become aware of the wider absence of Asian representations in Australian history and in wider notions of Australian identity.

The period, which marks the rise of a nationalist school of Australian art (the Heidelberg School), coincides with a time in which the government actively sought to prevent Chinese migration to Australia. The National Gallery of Victoria, Australia's oldest art gallery, was established in 1861, just 10 years 
after the Victorian gold rush that brought substantial revenue to the colony and record numbers of Chinese migrants to the region. Although the 'ancestors' invoked by Liu's Other Lives had been present in small numbers since early settlement, it was not until the mid-1800s that Chinese people reached sufficient numbers to become visible within Australian public culture. The Victorian and NSW goldfields attracted such substantial numbers of Chinese that by 1861 they made up 3.3 per cent of the total population. ${ }^{9}$ Their presence alarmed colonial governments to such a degree that Victoria introduced legislation to restrict Chinese immigration in 1855; New South Wales did the same in 1861, Queensland in 1877 and Western Australia in 1886. ${ }^{10}$ By 1901, the anti-Chinese lobby was led by some of the most prominent politicians of the day. Edmund Barton, Australia's first prime minister and one of the major architects of Federation, stated at the time:

The doctrine of the equality of men was never intended to apply to the equality of the Englishman and the Chinaman ... Nothing we can do by cultivation, by refinement, or by anything else, will make some races equal to others. ${ }^{11}$

As Liu Xiao Xian reminds us, there are no artists of Chinese descent represented in the early annals of Australian art history because socially, and later legally, people of Chinese descent were excluded from the category 'Australian'.

\section{Slippage number one: Australian monoculturalism}

It has recently become popular in government discourses to state that Australia has always been multicultural. ${ }^{12}$ These statements strike me as problematic because they risk obscuring or misrepresenting one of the most significant facets of Australian history - that Australia as a nation-state was founded on a principle of racial exclusion and a deliberate policy of monoculturalism. More importantly, this idea was enshrined in legislation that impacted directly on the cultural diversity of the resident population.

Australia's first act of legislation as a nation-state was the Immigration Restriction Act (1901), which effectively banned all Chinese migration to Australia, including family members of Chinese residents. The legislation precipitated a substantial decline in the Chinese Australian population - from 29,000 in 1901 to 6000 by $1947 .^{13}$ It was only after World War II that Chinese immigrants were allowed to become naturalised residents. The early postwar period saw increased migration, mainly from Hong Kong and Malaysia, but it was not until the late 1980s that the Chinese population once again reached the 1861 figure of 3.3 per cent of the total. ${ }^{14}$

Until the late nineteenth century, the Australian colonies held a relatively open stance on immigration in order to supply the open labour market. ${ }^{15}$ Hence the presence of Chinese merchants and labourers, Afghan cameleers, Malay and 
Japanese pearl divers and Pacific Islander plantation workers who are often invoked in the 'we have always been multicultural' narrative. However, the opening act of Federation sought the removal of these same people. Within the rhetoric leading up to Federation, these 'foreign' labourers were seen as competition for 'white' jobs and a threat to age-old (British) customs. The stridency of the clarion call to 'whiteness' is aptly summed up by a now famous quote from an 1887 Bulletin editorial, which states that '[n]o nigger, no Chinaman, no lascar, no Kanaka, no purveyor of cheap, coloured labour is an Australian'. ${ }^{16}$ Their removal was presented as necessary for the creation and constitution of an avowedly monocultural nation.

Historically, Australia as a nation-state was founded on a model of 'whiteness', which was actively engineered by immigration legislation. By Federation, the territorial negotiations (sometimes peaceful, sometimes violent) between the British colonists and the original inhabitants had already produced a well-developed set of uniquely 'Australian' images and narratives. An existing lexicon of 'Australian' identity was already in place - of British subjects out of place, but re-formed and made stronger within the crucible of a new landscape. Many academics writing on Australian history have argued that all narratives of 'white Australia' are ultimately about issues of territoriality and anxiety about possession of the land. ${ }^{17}$ What these narratives have in common is that they operate to promulgate the idea that it is normative and natural for British settlers and their descendants (Anglo-Australians) to have inalienable rights over the land of Australia - due to their possession of a superior culture, their historical struggles with and dominion over the natural landscape, their quintessentially 'Australian' character and so on. This narrative was further bolstered in public and political culture by the idea that there was an ever-present need to defend this natural order against the threat of Asian invasion. ${ }^{18}$

When Australian multiculturalism appeared some 70 years after the White Australia Policy, it did so as an entirely new paradigm. Our current readings of the 'success' or 'failure' of multiculturalism need to be tempered by an understanding of just how deeply embedded these narratives are. While multiculturalism has been in place for more than 30 years, the White Australia Policy was in place for more than 70, (and the founding myths begin as early as 1778). As cultural historian Ien Ang has written, while

the legal and formal-political structures of the white Australia policy itself are no longer in place, the mentality that nurtured it is still part of the deep structure of Australian culture. Culture, after all, is much more resistant to change than politics and law; culture is the longue duree of history. ${ }^{19}$ 


\section{Hou Leong's Crocodile Dundee}

About the time that Liu Xiao Xian's work was on display at Federation Square, a work of similar resonance was on display in the National Gallery of Australia. The work is one of a larger series entitled An Australian Series, where the artist Hou Leong has taken iconic images of Australianness (such as an 'Aussie' pub, an ANZAC Day march and the culture hero, Crocodile Dundee) and digitally inserted himself into the picture in order to draw attention to the absence of Asian representations within mainstream images of Australian identity. ${ }^{20}$ In these works Leong places himself in the centre of Australian culture as opposed to the periphery where non-Anglo Australians traditionally occupy only supplementary roles. ${ }^{21}$

Produced in 1994, Leong's Crocodile Dundee parodies one of this country's most famous exports, the quintessentially Australian Mick 'Crocodile' Dundee. The 1986 film Crocodile Dundee was directed by Peter Faiman and co-written by Australian comedian Paul Hogan, who also played the movie's eponymous lead. While the film poked fun at Australian stereotypes, it also served to reinforce these ideas, particularly to overseas audiences. In his artwork Leong has digitally reworked a production still from the movie and superimposed his face over that of Dundee. The effectiveness of the work is carried through the element of surprise: in the highly iconic image, we are expecting to see blonde-haired, blue-eyed Hogan as Dundee, not a man of Chinese descent. Leong's cheeky grin gives extra subtext - for while the original shows Hogan with his arms around the film's love interest (played by blonde-haired, blue-eyed Linda Kozlowski), this time it is the bespectacled Asian guy who 'gets the girl'.

Although Leong's work has a playful aspect, it also speaks to a real confusion and concerns shared by many Asian-Australians stemming from the disjuncture between their everyday lives - where faces on the street show people of myriad descent, not just Anglo-Australians, versus mainstream media, public culture and even political representation, which construct Australia as almost entirely a constituency of Anglo-Australians. Ultimately, the works provide testimony to the failure of Australian multiculturalism to overcome the dominant Anglo-Australian (white) cultural hegemony. 
Figure 7.2 Hou Leong, An Australian Series, Crocodile Dundee

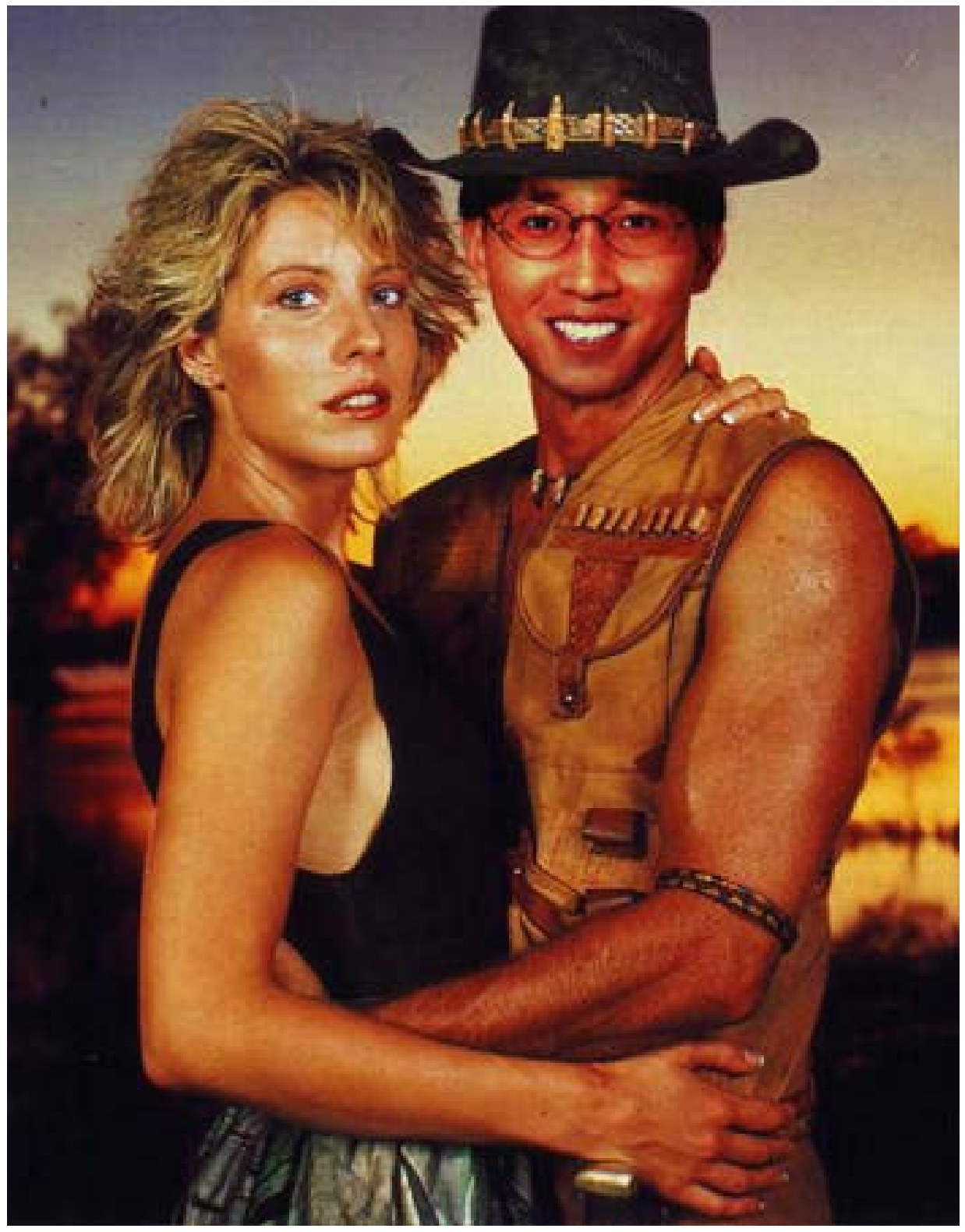

Hou Leong, An Australian Series, Crocodile Dundee, 1994; digital photograph, 70 x 50cm; Courtesy of the artist. 


\section{Slippage number two: Constructions of Australian identity}

Despite 30 years of bipartisan support for multiculturalism, governmental, public culture and popular constructions of citizenship and national identity continue to be dominated by an epistemological model of Anglo-Australian 'whiteness' as normative and central, in contrast with all other cultural or ethnic groups. Beneath this foundational episteme is a bicultural model of Australian identity that allows Aboriginal people to also be Australian, but only as a significant 'Other'. Despite a deeply entrenched and institutionalised history of racism, the fact that Aboriginal people are not asked 'Where are you really from' is fairly axiomatic given their autochthonous status. For non-Indigenous, non-Anglo Australians, their identity (the authenticity of their belonging) is always deferred to a third space in public discourses.

Today, most of the common markers or tropes of Australian identity are founded on images, events and material culture that are predominantly either Anglo-Australian or Aboriginal in origin. ${ }^{22}$ These tropes emerged during at a time when the dominant negotiations of national identity were between 'white Australians' (predominantly but not exclusively of British descent) and the original owners of the land. The Indigenous population's prior rights to sovereignty were denied as well as citizenship, but they could be not be 'returned' to their places of origin like the Asian and Pacific Islander populations. Although the 'Aboriginal problem' was noted, the general consensus at Federation was that Aboriginal people were a 'dying race' - hence unlikely to affect the future of 'white' Australia. The eugenic policies of assimilation (introduced from 1910 onwards) sought to further facilitate this process. ${ }^{23}$

The idea of Australia as a bastion of 'whiteness' persisted until well after World War II. The gradual disbandment of the White Australia Policy (between 1958 and 1973) was not merely a series of ideational shifts on the part of government; it saw changes to Australia's immigration legislation, which substantially transformed the cultural constituency of the Australian population. As demographer Graeme Hugo has noted, Australia underwent a massive transformation during the course of the twentieth century, from 'an overwhelmingly Anglo-Celtic, homogenous population in which 95.2\% had been born in Australia, the United Kingdom or Ireland, to one of the world's most multicultural societies'. ${ }^{24}$ Such rapid transformation is unparalleled elsewhere in the world.

Echoing this sentiment, historian Eric Richards has argued that the (relative) harmoniousness of this transformation can be read as an international success story for Australian 'multiculturalism'. ${ }^{25}$ The relative rapidity of the transformation from mono to multicultural has, however, led to a lag between older constructions of national identity based on a time when Australia was demographically and ideationally dominated by people of British descent and 
later constructions, which represent Australia in its current multicultural manifestation. As a result, the constructed imaginary of Australian national identity is based on a set of historical markers that no longer reflects the lived reality of today.

This disjuncture in Australian public culture might best be summed up by philosopher Jean Baudrillard's term 'simulacra', where the image, detached from its original referent, comes to possess such potency that it is the simulacrum that is sought as the authentic image, rather than the real-life referent. ${ }^{26}$ Because of their repeated and valorised presence, particular images have come to represent the authentic markers of Australian identity - even if these images no longer reflect the day-to-day lives of those they represent.

Although many of the dominant markers of Australian identity reflect an image of Australia that is no longer current, they still possess a strong emotional currency that can be used to great effect within the political milieu. Former Australian Prime Minister John Howard was particularly adept at playing on the idea of 'traditional' or 'old' Australia to generate a sense of nostalgia - a search for the 'real' Australia whose existence could be found only in the established mythical elements of the pre-multicultural nation. While some might have found appeal in the nostalgic constructs presented by Howard during his leadership, others felt decidedly uneasy. Many Australians felt understandably confused that the government was on one hand officially pursuing a policy of multiculturalism while on the other hand actively advocating assimilation and promoting Anglo-Australian (or British) traditions as the prime means of expressing Australian identity. ${ }^{27}$

In her 2007 analysis of narratives of Australian national identity, Catriona Elder has argued that there are two dominant narratives of Australian ethnicity that are played out concurrently in public culture; an older 'white Australia' story which perpetuates the idea of cultural homogeneity, and a newer 'multiculturalism' story which presents Australia as a nation of immigrants. ${ }^{28}$ In an interesting take on both narratives, the anthropologist Ghassan Hage has argued that, irrespective of which model they support, when Anglo-Australians debate these issues they are unwittingly sharing a common idea about national space, where both

White racists and White multiculturalists share in a conception of themselves as nationalists and of the nation as a space structured around a White culture, where Aboriginal people and non-White 'ethnics' are merely national objects to be moved or removed according to a White national will. ${ }^{29}$

Hage calls this the "White nation" fantasy - the idea that white Australians control the national space and that it is their right to decide who enters the 
country, and to define what is Australian and what is un-Australian. Hage's intent is not to offer a critique of multiculturalism per se (at least not in its guise as a doctrine of social equality). Rather, he is attempting to highlight some of the deeper structures in place in order to expose an underlying or foundational world view which says that white Australian citizens have more rights than non-white Australian citizens because they represent the central body, the 'true blue' Australians as opposed to just the 'new' Australians.

Hage argues that the dominant criteria of Australianness are constructed around 'whiteness' rather than Anglo-celtic heritage per se. As such 'whiteness' is something that many non-English speaking background migrants can also aspire to. 'Whiteness', he argues, is that which is constructed as authentic Australianness in opposition to Third World-looking (and indeed Fourth world-looking) people. Hage contends that many people from non Anglo-Australian backgrounds, such as central Europeans, now construct themselves as part of what he terms the "white fantasy", where they self-identify as occupying a central national identity and have the right to speak about Third World-looking 'Others'. 30

Hage's arguments do not mean, however, that we should write off the historical importance of 'Britishness' in the formation of an Australian national consciousness. After all Britishness is the apotheosis of whiteness - at least in all of the founding myths. Australia's 'birth' as a nation occurred when Britain's geographical and ideational domination was at its height. It is not surprising then that a deeply embedded notion of a hierarchy of whiteness continues to haunt Australian public culture long after the demise of Britain's Empire.

\section{Owen Leong's second skin}

In Owen Leong's video installation Second Skin, the artist draws attention to the European fascination with Asian bodies as 'Other' - as objects of simultaneous repulsion and desire - evoking an intertwined history of European colonialism and Orientalism. The artist's face is filmed in close-up as honey is poured over his head in a single slow-motion sequence. As his hands rub the viscous liquid across his face it is unclear whether he is in pleasure or in pain. The video is deliberately ambiguous; what at first viewing appears to be a sensuous act, over time takes on a more sinister tone - the 'sweet' honey becomes cloying, sticky and uncomfortable. Leong often uses milk and honey in his work as 'racial constructs', as metaphors in which milk equals white and honey equals yellow. ${ }^{31}$ Much of his practice involves staging deliberate interventions against homogenising stereotypes based on Eurocentric constructions of race, in which his own body becomes the platform for alternative identities. 
Figure 7.3 Owen Leong, Still from the video installation Second Skin.

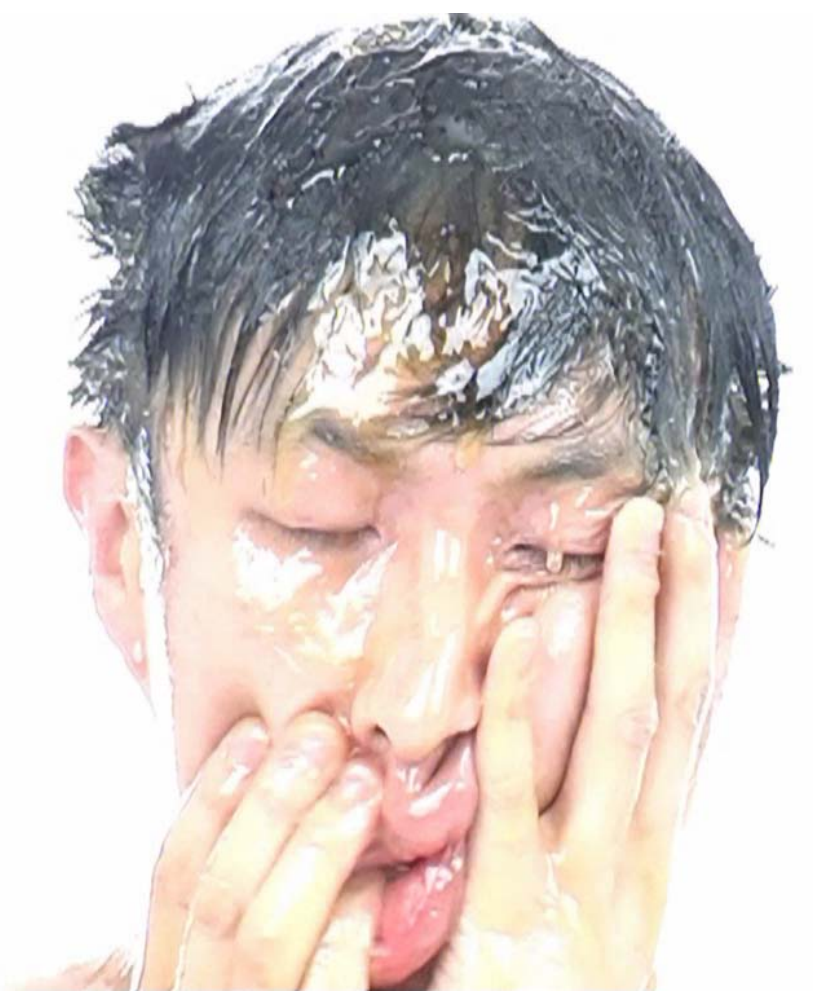

Figure 7.3 Owen Leong, Still from the video installation Second Skin, 2003; Courtesy of the artist and Uber Gallery, Melbourne.

Leong is highly conscious of growing up in a country dominated by 'whiteness'. He comments:

As an Australian-born Chinese having lived in Australia all my life, I have always been made painfully aware of mainstream Australia's racial anxiety, its tenuous grip on 'whiteness' as a position of power. ${ }^{32}$

As an Asian-Australian, he is acutely aware of dominant discourses in Australian public culture that deny him an authentic Australian identity. His work raises a very important point. Although he represents the ideal example of assimilation - born in Australia and possessing a completely Australian 'habitus' (that is, his way of walking and talking, his outlook and social dispositions) - he can never truly be an accepted part of the mainstream. As long as the mainstream is defined as Anglo-Australian, it does not matter how completely 'assimilated' he is, how often he says 'crikey' or how many crocodiles he wrestles; he is forever to be excluded from the category of 'real Australian'. As Leong states, 'It doesn't matter how Australian I am, I can't escape my Asian face. ${ }^{33}$ 


\section{Slippage number three: Assimilation}

The period directly after World War II saw the beginnings of a major demographic transformation in Australia. Like other Western liberal democracies, Australia was encouraged by the international community to provide refuge for the significant numbers of displaced persons created by the war. This, along with an imperative to 'populate or perish', led to the acceptance of small numbers of refugees from non-English-speaking European backgrounds (Asian immigrants were not accepted until after 1966). 'Assimilation' was the term used during the late 1940s and 1950s for government policies aimed at 'settling' these postwar migrants of non-English-speaking backgrounds. During the 1960s, the term 'integration' replaced 'assimilation', but the government policies essentially remained the same, that immigrants should shed their previous cultural personas and adopt the language and customs of their host society as quickly as possible in order to become fully integrated into the dominant Anglo-Australian culture. ${ }^{34}$ By the 1970s, assimilation had fallen out of political favour, replaced with a new paradigm, multiculturalism, which advocated cultural pluralism rather than cultural homogeneity.

However, despite its fall from political grace, the concept of assimilation did not disappear entirely. In a work published earlier this year, historian Anna Haebich has noted the recent re-emergence of assimilationist narratives within Australian political culture:

[W] hile the word assimilation is rarely mentioned, more than a trace of its essence remains in official pronouncements on national values, citizenship and the practical integration of Aboriginal communities. This paradox of public denial of assimilation and hidden allegiance to its tenets can be explained in terms of 'retro-assimilation'. 35

During the conservative political climate of the Howard era (1996-2007) Australia experienced a significant shift in political discourses on cultural diversity. Although it is not within the scope of this essay to discuss the 'return to the right' of Australian public culture during the Howard era, it is worth briefly noting some significant events that occurred during this time, which benchmark a return of neo-assimilation discourses in Australia and which, according to political analyst Rogers Brubaker, reflect a wider global trend. ${ }^{36}$ Many of these retro-assimilation discourses have been fuelled by the tensions generated since 2001 regarding border security, immigration and the spectre of home-grown terrorism. The terrorist attacks on 'Western' targets by militant Islamic groups-beginning with the attacks of 11 September 2001 on US soil, followed by attacks in Bali (October 2002), Madrid (March 2004), London (July 2005) and Mumbai (November 2008) - have resulted in global anti-terrorist rhetoric and increased racial tension within liberal multicultural nations. 
These tensions contributed to Australia's first race riots, in December 2005, which erupted in the Sydney beachside suburb of Cronulla - allegedly between young males of Anglo and Lebanese-Australian descent. In the wake of these events, Prime Minister Howard used his 2006 Australia Day speech to openly critique multiculturalism, stating, 'We've drawn back from being too obsessed with diversity to a point where Australians are now better able to appreciate the enduring values of the national character that we proudly celebrate and preserve.' For him multiculturalism was associated with narratives that, he claimed, falsely presented 'old Australia' as 'xenophobic, racist and monocultural' ${ }^{37}$ He also re-iterated that Australia's national character was derived from Britain and made clear his commitment to the values of 'old Australia'.

Interestingly, Howard began his speech by noting the lack of a predeterminate 'test of Australianness' for aspiring citizens, saying that immigrants came to Australia 'because they want to be Australians'. He added, 'The irony is that no institution or code lays down a test of Australianness. Such is the nature of our free society. ${ }^{38}$ Despite the 'free nature' of Australian society, by September 2007, the government had introduced a new citizenship test, which required potential citizens to demonstrate their knowledge of the English language and the traditions and values of Australian society (as defined by the government). The test was deemed to somehow inculcate a greater 'Australianness' in new migrants, leading to more effective social integration.

Sadly, the test has proved anything but inclusive. An independent review of the test commissioned in 2008 under the newly elected Rudd Government (which replaced the Howard Government a month after the test was made active) found the test to be 'flawed', 'intimidating' and 'discriminatory'. ${ }^{39}$ The test forebodingly echoed Australia's original citizenship test, the infamous 1901 Dictation Test, designed to keep non-white migrants out of the country. Richard Woolcott, who headed the 2008 review, supported these assumptions by stating that 'the standard of English required [in the citizenship test] was too high and discriminated against non-English speaking migrants' ${ }^{40}$ The irony of the citizen test is that it promotes the notion that 'Third World-looking' immigrants must learn to be authentic Australians (part of the mainstream), while at the same time denying these groups entry into the mainstream by defining it solely in terms of Anglo-Australian identity and cultural expressions. This is the catch-22 of Australian citizenship as it currently stands.

\section{Kate Beynon's where is your original home?}

Much of Kate Beynon's art revolves around her personal experiences of hybridity, and the complexity of adequately representing her identity as an Australian with Welsh, English, and Norwegian ancestry on her father's side and 
Chinese-Malaysian ancestry from her mother. Her work speaks to some of the complexities of identity negotiation in a multicultural (and increasingly transnational) society and resists simplistic or singular representations of migrant identity. Beynon's work has evolved its own distinct lexicon, which draws on the visual genres of Eastern and Western comic book graphics, Chinese calligraphy and late-twentieth-century graffiti art. Many of her works are inspired by old Chinese stories and folk heroes, which she re-presents in modern situations. One of her most enduring representations is $\mathrm{Li} \mathrm{Ji}$, based on a fourth-century Chinese heroine who stepped outside her traditional cultural boundaries and saved her village from a giant python. In Beynon's work, Li Ji appears reincarnated into the modern world in different guises as a symbol of the 'global' citizen. ${ }^{41}$ Where is your original home was one of 11 prints based on the animated video work Li Ji: Warrior Girl, 2000, where Li Ji is portrayed as a Chinese Australian young woman on a journey into Melbourne's Chinatown. As she travels by tram and later on foot, she experiences flashbacks to her past life as the Li Ji from the 4 th century fable. ${ }^{42}$

In the 2001 work, Where is Your Original Home?, Li's face appears to be exploding from the canvas like a cartoon punch. Beynon presents her protagonist against a backdrop of what appears to be writing in both graffiti tag-style and kanji script. The text that frames Li's face is stylised but readable as the question, 'Where is your original home?' - a phrase that was taken from the socializing section of a Chinese language guide which Beynon took to China when she visited for the first time in 1995 on a study tour to learn Chinese. She comments, 'I was interested in how the intention of this question can vary from friendly and conversational, to hostile and exclusionary.' ${ }^{43}$ The phrases evoke Beynon's ambivalence regarding assumptions commonly made about her cultural identity. In certain social contexts, asking someone 'where are you from?' immediately renders that person 'out of place' — a foreigner. Many non Anglo-Australians will be familiar with the scenario of being asked by a stranger, 'where are you from?'. Answering with 'Wollongong' or 'Brunswick' or 'Mt Isa' then leads to the all-too-familiar 'But where are you really from?'. Underlying the seemingly innocent question, a number of assumptions about territoriality and belonging are being played out.

While Beynon's work has often been included in exhibitions of 'Asian-Australian' art, her practice revolves around a reiteration of the complexity of personal identity. Beynon says her work explores

the multi-layered experiences of people negotiating 'hybrid' or 'mixed' identities produced by a nexus of cultural influences such as heritage, family histories, travel, language, paths of migration and a sense of belonging. ${ }^{44}$ 
Figure 7.4 Kate Beynon, Where is Your Original Home?

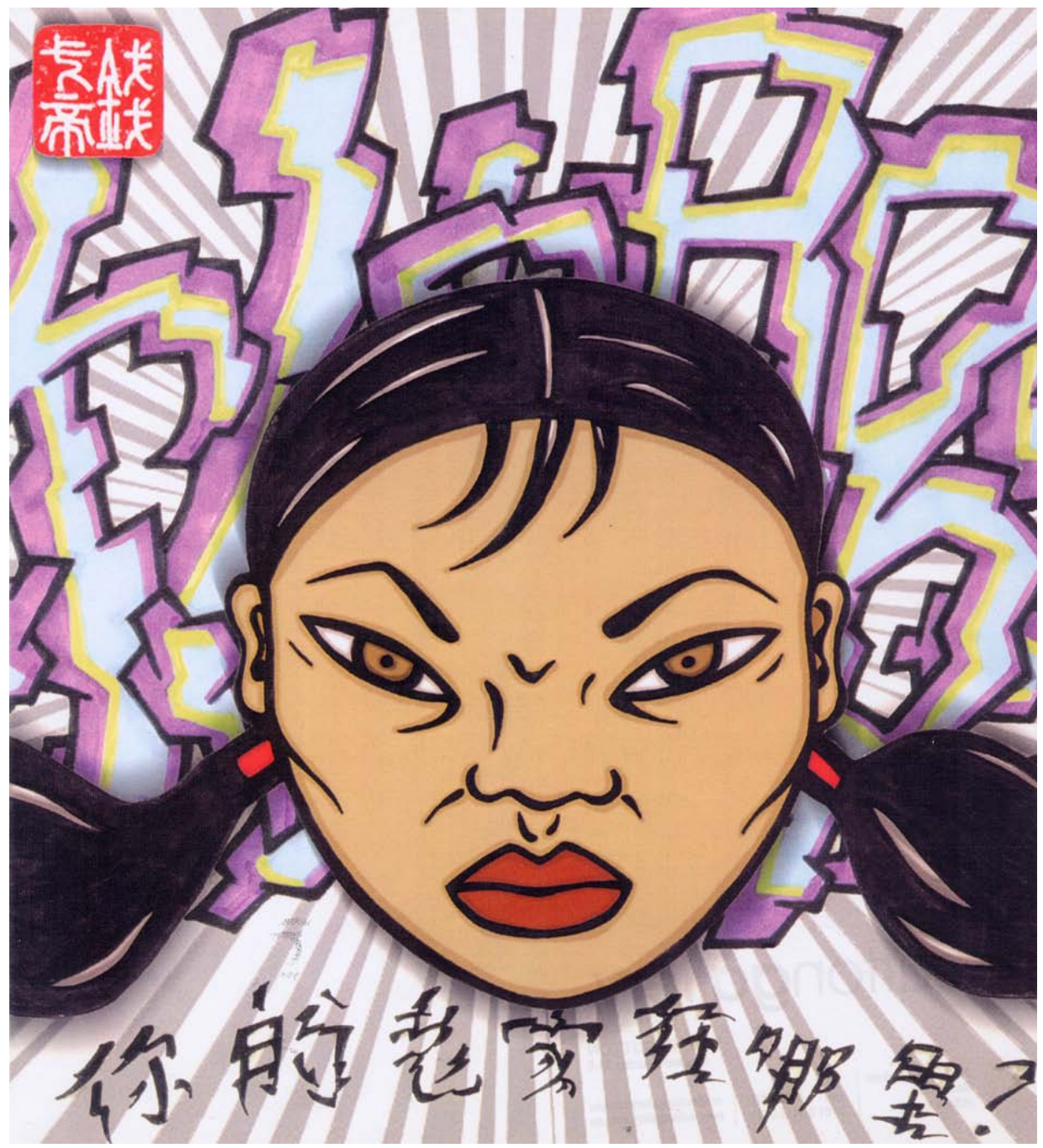

Figure 7.4 Kate Beynon, Where is Your Original Home?, 2000; digital photographic print, 90 x 84cm; Courtesy of the artist and Sutton gallery, Melbourne.

Her insistence on the multiplicity of her personal identity (her complex hybrid self) evokes one of the interesting effects of contemporary multiculturalism, which is the privileging of ethnicity over other aspects of identity (gender, class, sexual orientation or social status, to name a few). Within this model, people tend to be accorded a single dominant ethnic identity, irrespective of their personal history. This is equally true of those of Anglo-Australian descent. Recently, Andrea Witcomb has commented on the rise of multiculturalism as the primary means of representing diversity in Australian museums. ${ }^{45}$ The same can be said of public culture writ large. While 30 years of multiculturalism have 
not successfully shifted some of the older stereotypes of Anglo-Australia, they have been very successful in making the concept of migration and ethnic diversity a primary locus for debating and defining cultural diversity within public culture. These presentations of ethnicity promote the idea that a person has only one dominant ethnic self - and that this ethnic self dominates all other aspects of identity.

As Kate Beynon's work suggests, this rendering of identity is far too simplistic. According to the Australian demographer Charles Price, around 45 per cent of the total population has three or more ancestries. "Moreover," he adds, "it is clear that many Australians of mixed ethnic origin are not simply mixtures of English, Irish, Scottish and Welsh, but have at least some elements of non-Anglo-Celtic in their ancestry." 46 While people are often required to assert one dominant choice of ethnicity, the reality is that they are likely to see themselves in far more complex ways. Likewise, at any given time, other markers of identity will predominate over ethnic heritage. Thus, in the flux of everyday living, people will self-select different aspects of their identity according to changing social contexts. Multiple variables contribute to identity and, for many people, 'ethnicity' might be the least relevant on a personal scale.

The politicians who drafted the original framework for Australian multiculturalism were aware of the complexities of this issue. In its original incarnation, Australian multiculturalism, as represented by Grassby, was intended to shift older hegemonic models of Anglo-Australian identity and to equalise differences. ${ }^{47}$ However, in the model of 'cultural difference' which has emerged under (or perhaps despite) three decades of multiculturalism, only some people are deemed different. Anglo-Australians have been portrayed as a single homogenous ethnic group which has enduring values rather than diverse cultural origins, while all other Australians have been portrayed as having an inescapable surfeit of culture which somehow prevents them acting as individual agents capable of making personal and autonomous (rather than culture-group) decisions.

\section{Slippage number four: Australian multiculturalism}

Australia, following Canada, was one of the first countries to adopt a formal national policy on multiculturalism. ${ }^{48}$ In the case of Canada, this meant a national policy of bilingualism and recognition of both Anglo and Franco-Canadian cultural traditions. In Australia, however, it was taken up in a more ambitious manner. Under the progressive Whitlam Government (1972-75), multiculturalism was presented as an ideal response to Australia's increasing cultural diversity, resulting from changes to immigration legislation since World War II. Whitlam's flamboyant Minister for Immigration Al Grassby is credited as one of the 'founding fathers' of Australian multiculturalism. Of Irish and Spanish-Chilean parentage, Grassby, rejected prior citizenship models in which migrants from non-English speaking backgrounds were expected to efface of all prior cultural 
ties in favour of total immersion or 'assimilation' into Anglo-Australian culture. Grassby wanted to replace the assimilation model with a more pluralist approach which was better able to represent the lived reality of post World War II Australia.

In the first official reference to multiculturalism, a 1973 speech by Al Grassby entitled, A multi-cultural society for the future, there appears a real desire to shift older hegemonic models of Anglo-Australian identity. Grassby makes notes of the absence of images of non Anglo-Australian cultural representation within public culture and especially the media. ${ }^{49}$ He comments, "How often do our television screens reflect anything like the variety of migrant groups encountered in a real-life stroll through out city streets, or particularly, near city suburbs?"50 While his comments provided the stimulus for the 1978 Galbally Report, which in turn provided the framework for the establishment of Australia's Special Broadcasting Service (SBS), thirty years on, Grassby's statements continue to have direct relevance. ${ }^{51}$

The policy reforms which accompanied Australia's adoption of multiculturalism were soon reflected within the arts and heritage sector. Since the mid to late 1970s shifts in Australia's immigration policies have seen a promulgation of 'multicultural' awareness generally, as well as specific funding for multicultural artists and public programs through government sponsored organizations such as the Australia Council and the Office of Multicultural Interests. During the 1980s and 1990s, the formation of the European Union and US market protectionism led Prime Ministers' Bob Hawke and his successor Paul Keating to turn to Asian markets for economic salvation. ${ }^{52}$ This shift in political axis from 'West' to 'East' resulted in a new 'branding' of Australia as part of the Asia Pacific region. It also led to a significant geo-political realignment of Australian identity. The period under Keating (1991-1996) marked the zenith of Australian 'multiculturalism' with the strength of government support reflected in both government rhetoric and funding.

The 1996 federal election of a Liberal-National Coalition Government led by John Howard was followed by the 1997 collapse of the Asian economic markets. A noticeable realignment back towards the West soon followed. Although the Coalition continued (at least tacitly) to support multiculturalism as an official government policy, Howard's dislike of the policy of multiculturalism was well known. ${ }^{53}$ As mentioned earlier in this discussion, the late 1990s and early 2000s were marked by a conservative shift in political discourses on cultural diversity, which both reflected and were fuelled by global anti-terrorist rhetoric and an increasing tightening of border security.

In 2007, the election of a Labor government, led by Kevin Rudd, had many analysts predicting a return of stronger Austral-Asian regional links. Those seeking a return to Australia's' prior traditions of advocating multiculturalism, 
however, seem doomed to be disappointed. While the original intent of multiculturalism was to encourage Australian migrants to retain their unique languages and cultural expressions, this maintaining of difference is increasingly seen as polemical. A continued retreat from multiculturalism is evident from the current Labor Government (as well as the Liberal Opposition).

\section{Conclusion: But where are you really from?}

A 'seismic shift' from multiculturalism to assimilation or civic integration discourses is, as Christian Joppke notes, a global, twenty-first century phenomenon. ${ }^{54}$ Yet as I have argued, the underlying foundation of assimilation narratives is the idea that social cohesion can only occur with cultural homogeneity. At the same time these narratives often conflict with equally held ideas about democratic citizenship. Historian Ann Mari Jordens has argued that a country's citizenship legislation 'reveals its conception of the ideal citizen, and the qualities required by foreigners if they are to be accepted into the community of the nation'.55 Since 1901, successive Australian governments have implemented a number of citizenship models as part of the material instrument of socially engineering a nation. Although these government policies (immigration restriction, assimilation and multiculturalism) have differed radically in scope, all have relied on the premise that citizenship is the teleological end point of Australian identity. The promise promulgated to migrants is that the bureaucratic award of citizenship automatically conveys a sense of belonging in the imagined community of the nation. As Geoffrey Brahm Levy notes, however, this 'overlooks the fact that one can enjoy equal citizen[ship] rights and equal opportunities and still be socially alienated'. 56

As I have argued in this essay, and as the work of artists Liu Xiao Xian, Hou Leong, Owen Leong and Kate Beynon so effectively illustrate, while Australian policies of multiculturalism have been effective in repositioning Australia as a culturally diverse nation, they have failed to secure a sense of true belonging for many of its citizens. Likewise, multiculturalism's proposed 'antedote', integration or assimilation, currently promotes a model which by its very nature successfully resists true social parity. Surely there is scope for a narrative that can celebrate the achievements of the nation as a pluralist democracy, which recognises that the commonality of being Australian comprises myriad different experiences and backgrounds. The material reality of a multicultural population versus the ideational imaginary of white Australia needs to be effectively negotiated. This disjuncture will need to be mediated by government in ways more sophisticated than a retreat to a nostalgic longing for the past or a blithe assertion that 'we have always been multiculturalists'. 


\section{ENDNOTES}

1 See, for example, Brubaker, Rogers 2001, 'The return of assimilation? Changing perspectives on immigration and its sequels in France, Germany, and the United States', Ethnic and Racial Studies, vol. 24, July, pp. 531-48; Back, Les et al. 2002, 'New Labour's White Heart: Politics, multiculturalism and the return of assimilation', The Political Quarterly, vol. 73, no. 4, pp. 447-54; Haebich, Anna 2008, 'Introduction', Spinning the Dream: Assimilation in Australia 1950-1970, Fremantle Arts Centre Press, Western Australia. For an excellent analysis of current debates surrounding the 'crisis of multiculturalism', see Lentin, Alana and Titley, Gavan 2008, Questioning the European 'crisis of multiculturalism', Presented to Questioning the European 'Crisis of Multiculturalism': An International Colloquium, National University of Ireland, Maynooth, 12 December 2008, viewed 11 May 2009, <http://www.sussex.ac.uk/sociology/1-4-11.html> For a comprehensive Australian perspective see Geoffrey Brahm Levey 2008 (ed.), Political Theory and Australian Multiculturalism, Bergahn Books, New York, Oxford. The most noted critique of multiculturalism comes from Nathan Glazer in his 1997 publication (We Are All Multiculturalists Now, Harvard University Press, Cambridge, Mass.).

2 Following Richard White, and Catriona Elder, I take from the outset that governments consciously manipulate constructions of citizenship and national identity as part of their governing strategy and that both multiculturalism and assimilation, as key organising principles of a government policy, have impacted directly on narratives of Australian identity. See Elder, Catriona 2007, Being Australian, Allen \& Unwin, Crows Nest, New South Wales and White, Richard 1981, Inventing Australia: Images and identity 1688-1980, Allen \& Unwin, Sydney.

3 I recognise that the term 'Asian-Australian' is an arbritrary one which may erroneously imply shared identity between people from substantially different geo-historical backgrounds. However in relation to this article the term is useful to denote a broad marker of identity which exists in opposition to the category 'Anglo-Australian'. Liu Xiao Xian, Hou Leong, Owen Leong and Kate Beynon have very different personal histories, but they share some common experience as people with Asian ancestry who live in a multicultural nation dominated by Anglo-Australian cultural hegemony. Moreover, all four artists seek to express through their art practice the complexities of negotiating cultural identity in multicultural Australia.

4 I should note that this is not an art-history paper. Rather, I am interested in these works as personal and political narratives, which tell a larger story.

5 Hage, Ghassan 1998, White Nation: Fantasies of white supremacy in a multicultural society, Pluto Press, Annandale, New South Wales, p. $18 \mathrm{ff}$.

${ }^{6}$ Raffel, Suhanya 2007, Binary Vision: My other lives Liu Xiao Xian, Exhibition commentary, Queensland College of Art, Griffith University, 6-29 June 2007, cited on Contemporary Art Centre of South Australia website, viewed 14 April 2009,

$<$ http://www.cacsa.org.au/publications/broadsheet/BS_v30no3/bs_07.pdf >

7 Stills Gallery 2001, My Other Lives, Liu Xiao Xian, Exhibition commentary, Stills Gallery, Sydney, 14 February - 10 March 2001, cited on Stills Gallery website, viewed 18 February 2009,

<http://www.stillsgallery.com.au/exhibitions/2001/index.php?obj_id=2001_02\&nav=3>

8 Ibid.

9 'Explore the Harvest of Endurance Scroll-Australian goldrush', National Museum of Australia website, viewed 15 April 2009,

$<$ http://www.nma.gov.au/collections/collection_interactives/harvest_of_endurance_html_version/> See also 'The Australian goldrush', Australian Government Culture and Recreation Portal, viewed 15 April 2009, <http://www.cultureandrecreation.gov.au/articles/goldrush/>

10 'Explore the Harvest of Endurance Scroll-Anti-Chinese violence; Lambing Flat riots'.

11 Barton, Edmund 1901, Committee Debate on the Immigration Restriction Bill, Commonwealth Parliamentary Debates, 26 September 1901, p. 5233.

12 This view seems to have acceptance across a wide range of government sectors, including: Comrie, Neil 1995, Policing multicultural Australia, Paper presented by the Chief Police Commissioner of Victoria to Australian Institute of Criminology Crime in Australia First National Outlook Symposium, Canberra, 5 and 6 June, p. 1; Department of Immigration and Citizenship 1997, Multicultural Australia: The way forward, Message from Council Chairman, Government of Australia, Canberra, p. 1; National Archives of Australia, Research Guide-Immigration to Australia, 1901-39, p. 1.

13 'Explore the Harvest of Endurance Scroll-Politics and racism'.

14 'Explore the Harvest of Endurance Scroll-Australian goldrush'. 
15 Kalantzis, Mary 2001, Recognising Diversity, NSW Centenary of Federation Committee Barton Lectures, no. 3 , p. 4.

16 Bulletin, 2 July 1887.

17 Despite coming from differing disciplines and focal points, a significant number of Australian academics writing on Australian narratives of 'whiteness' have argued that these narratives have their origin in issues of territoriality and anxiety about possession of the land. See, for example: Elder, Catriona 2007, Being Australian, Allen \& Unwin, Crows Nest, New South Wales; Hage, White Nation; Moreton Robinson, Aileen (ed.) 2004, Whitening Race: Essays in social and cultural criticism, Aboriginal Studies Press, Canberra; Papastergiadis, Nikos 2004, 'The invasion complex in Australian political culture', Thesis Eleven, no. 78, pp. 8-27; White, Richard 1981, Inventing Australia: Images and identity 1688-1980, Allen \& Unwin, Sydney.

18 See, for example, Papastergiadis 'The invasion complex in Australian political culture', pp. 8-27; Elder, Being Australian, pp. 122-7.

19 Ang, Ien 2001, Intertwining histories: heritage and diversity, NSW History Council Lecture, Government House, Sydney, 24 September. Reproduced in full in Australian Humanities Review issue 24, December 2001, viewed 1 May 2009,

<http://www.australianhumanitiesreview.org/archive/Issue-December-2001/home.html>

20 Images that provide the backdrop to Leong's An Australian series include an 'Aussie' pub, an Anzac Day march, a group of postwar European migrants arriving by ship and an Ampol advertisement showing a blonde-haired, blue-eyed man wearing a Drizabone, seated on a motorbike with a cattle dog and featuring the line 'I'm as Australian as Ampol'.

21 Kho, Tseen 2003, “'Angry yellow men”: cultural space for diasporic Chinese masculinities', in Kam Louie and Morris Low (eds.) Asian Masculinities: The meaning and practice of manhood in China and Japan, Routledge Curzon, London, pp. 220-243, p. 230.

22 I have deliberately referred to Aboriginal Australians rather than using the more encompassing term 'Indigenous Australians', since within historical constructions of Australianness, Torres Strait Islanders are rarely represented or falsely incorporated into the category 'Aboriginal', rather than recognised as a historically and ethnically separate group.

23 In 1997, a Human Rights and Equal Opportunity Commission report found that Australian government policies (from about 1910 to the early 1970s), aimed at the removal of Indigenous children of 'mixed descent' from their parents, were, ultimately, formulated to end the existence of 'Aborigines' as a distinct people and thus amounted to genocide. Human Rights and Equal Opportunity Commission 1997, Bringing Them Home: Report of the National Inquiry into the Separation of Aboriginal and Torres Strait Islander Children from their Families, Commonwealth of Australia, Canberra, 1997.

24 Hugo, Graeme 2002, 'A century of population change in Australia', ABS Year Book Australia 2002, Australian Bureau of Statistics.

25 Richards, Eric 2008, Destination Australia: Australian immigration from 1901, UNSW Press, Sydney.

26 Baudrillard, Jean 1994, Simulacra and Simulation, Ann Arbor Press, University of Michigan.

27 See for example, Metherell, Mark 2007, 'Immigration chief at odds with PM over assimilation', Sydney Morning Herald, 22 May 2007.

28 Elder, Being Australian, p. 115.

29 Hage, White Nation, p. 18.

30 Ibid., p. 18.

31 'Man of milk and honey', BBC News, Manchester edition, 2006, viewed 16 April 2009, <http://www.bbc.co.uk/manchester/content/articles/2006/06/23/230606_owen_leong_feature.shtml> 32 Ibid.

33 Owen Leong, in conversation with the author.

34 Galligan, Brian and Roberts, Winsome 2003, Australian multiculturalism: its rise and demise, Paper presented at the Australasian Political Studies Association Conference, University of Tasmania, Hobart, 29 September - 1 October 2003, p. 2.

35 Haebich, Spinning the Dream, p. 1.

36 Brubaker, 'The return of assimilation?', pp. 531-48.

37 Howard, John 2006, A sense of balance: the Australian achievement in 2006, Address to the National Press Club by the Prime Minister, Parliament House, Canberra, 25 January 2006, viewed 5 March 2009, <http://www.australianpolitics.com/news/2006/01/06-01-25_howard.shtml> 
38 Ibid.

39 Evans, Chris 2008, Moving forward...improving pathways to citizenship, Government press release, 22 November 2008, p. 1 .

40 Cited in 'Citizenship test overhaul', Courier Mail, 29 August 2008.

41 Brown, Ruth and Bailey, John 2006, 'Planet art', Age, 30 July 2006, viewed 1 May 2009, $<$ http://www.theage.com.au/news/arts/planet-art/2006/07/27/1153816319365.html>; 'Kate Beynon: artist's bio', Sutton Gallery website, <http://www.suttongallery.com.au/artists/artistprofile.php?id=18> 42 In later works such as the animated video From the Lives of Li Ji , 2002, and the painting Li Ji: Future Dream, 2003, Li Ji appears has having multiple lives, including a futuristic life as a 'multi-racial' figure. These works led to the Hybrid Faces Project, 2004, featuring faces of mixed but 'non-defined' racial heritage or background, which highlighted the issues experienced and imposed upon people of mixed backgrounds. Beynon's last solo exhibition Auspicious Charms for Transcultural Living, 2008 further developed the idea of the 'global citizen', of people affected by and embracing aspects of 'transcultural' life, whether through their own heritage, their relationships with friends and partners, through travel, work and/or experiences. Email correspondence, Kate Beynon to Anna Edmundson, dated 8 June, 2009.

43 Beynon to Edmundson, 8 June, 2009.

44 'Artist's statement', Sutton Gallery,

$<$ http://www.suttongallery.com.au/artists/artistprofile.php?id=18>

45 Andrea Witcomb, this volume.

46 Charles Price cited in Galligan and Roberts, Australian Multiculturalism. p3.

47 Grassby, A. J. 1973, A Multi-Cultural Society for the Future, Australian Government Publishing Service, Canberra.

48 Brahm Levy, Political Theory and Australian Multiculturalism, p. 1.

49 Grassby, A Multi-cultural Society for the Future.

50 Ibid.

51 Galbally, Frank et. al, 1978, Review of Post-Arrival Programs and Services, Australian Government Printing Service, Canberra. As well as the establishment of SBS, the 1978 Galbally report was instrumental in recommending of a range of essential services to assist incoming migrant groups which were not in existence previously. Although my interest here is in 'multiculturalism' at its widest frame - as a government platform which directly impacts on changing conceptions of Australian citizenship and national identity - it is necessary to acknowledge that the adoption of multiculturalism facilitated real improvements to the migration experience on a material level.

52 Chiu, Melissa 2001, Asian-Australian artists: Recent Cultural Shifts in Australia, unpublished conference paper delivered at Apexart bi-annual conference, Inside Out: Reassessing International Cultural Influence, Rio de Janiero, July 3-9, 2001.

53 Galligan and Roberts, 'Australian Multiculturalism', p. 12.

54 Christian Joppke, cited in Phillips, Anne 2007, Multiculturalism Without Culture, Princeton University Press, Princeton, p. 4.

55 Jordens, Ann-Mari 1996, Redefining Australians: immigration, citizenship, and national identity, unpublished conference paper, abstract, Nationalism and National Identity (Fourth HRC Summer School), The Australian National University, Canberra, 12-16 February 1996, p. 1.

56 Brahm Levy, Geoffrey 2008, 'Multicultural Political Thought in Australian Perspective', in Geoffrey Brahm Levy (ed.) Political Theory and Australian Multiculturalism, Berghahn Books, New York and Oxford, p. 16. 